\title{
Gambaran Penyebab Bayi Lahir Mati (Stillbirth) Pada Proses Persalinan
}

\author{
Selly Melasti Putri ${ }^{1}$, Widya Maya Ningrum ${ }^{2}$ \\ ${ }^{1}$ Sekolah Tinggi Ilmu Kesehatan Respati Tasikmalaya, Indonesia \\ ${ }^{2}$ Prodi D III Kebidanan, Fakultas Ilmu Kesehatan, Universitas Galuh, Indonesia \\ Corresponding Email: smelasti@yahoo.co.id \\ (Diterima 18-03-2019; disetujui 25-04-2019; dipublish 09-05-2019)
}

\begin{abstract}
Abstrak
Stillbirth merupakan kematian bayi terjadi sebelum lahir, tetapi setelah kehamilan 20 minggu. Faktor penyebab stillbirth adalah faktor penolong, tempat persalinan dan penyulit persalinan. Data di Kabupaten Tasikmalaya, angka kejadian stillbirth tahun 2016 sebanyak 213 kasus (0.68\%), pada 2017 sebanyak 187 kasus (0.6\%). Tujuan penelitian ini adalah untuk mengetahui gambaran penyebab bayi lahir mati (stillbirth) pada proses persalinan di kabupaten Tasikmalaya tahun 2017. Penelitian ini bermanfaat bagi bidan sebagai tolak ukur dalam meningkatkan kualitas pelayanan dengan memberikan asuhan kebidanan pada ibu bersalin khususnya pada kasus kejadian lahir mati yang disebabkan karena proses persalinan.Jenis penelitian ini adalah kuantitatif dengan metode deskriptif. Populasi dalam penelitian ini ibu yang mengalami bayi lahir mati sebanyak 187 kasus. Kemudian data dikumpulkan menggunakan data sekunder diperoleh dari buku KIA dan otopsi verbal kemudian dianalisis secara deskriptif berupa tabel distribusi frekuensi. Hasil penelitian menunjukkan bahwa penolong persalinan pada ibu dengan bayi lahir mati sebagian besar adalah bidan (71.1\%), tempat persalinan pada ibu dengan bayi lahir mati sebagian besar di RSU (72.2\%) dan Penyulit proses persalinan pada ibu dengan bayi lahir mati sebagian besar adalah letak bokong $(10.7 \%)$.Kesimpulan dari penelitian ini adalah kasus stillbirth sebagian besar penolong persalinan adalah bidan, bertempat di rumah sakit dan disebabkan oleh letak sungsang. Oleh karena itu bidan disarankan melakukan upaya sedini mungkin untuk pencegahan komplikasi pada ibu selama kehamilan, persalinan dan pada bayi dan mengoptimal pemberian pelayanan kebidanan seperti penyuluhan kepada ibu hamil pentingnya persalinan oleh nakes di fasilitas kesehatan.
\end{abstract}

Kata kunci : Penyebab, Stillbirth, Persalinan

\begin{abstract}
Stillbirth is an infant mortality occurring before birth, but after 20 weeks of pregnancy. Factors that cause stillbirth are the auxiliary factors and place of labor and complication of labor. Data in Tasikmalaya regency, the incidence of stillbirth year 2016 as much as 213 cases (0.68\%), in 2017 as many as 187 cases (0.6\%). The purpose of this study is to know the description of the cause of stillbirth in the birth process in Tasikmalaya district in 2017. This study is useful for midwives as a benchmark in improving the quality of services by providing midwifery care to mothers especially in cases of birth-causing deaths caused because of the labor process. This research type is quantitative with descriptive method. The population in this study of mothers who have stillborn infants as many as 187 cases. Then the data were collected using secondary data obtained from KIA book and verbal autopsy then analyzed descriptive. The results showed that maternity assistants in mothers with stillborn babies were mostly midwives (71.1\%), maternal places with stillborn babies mostly in public hospitals (72.2\%) and complications of delivery in mothers with stillbirths were mostly breech position (10.7\%). The conclusion of this study is the case of stillbirth most of the birth attendants are midwives, housed in the hospital and caused by breech position. Therefore midwives are advised to make early efforts to prevent maternal complications during pregnancy, childbirth and infant and to optimize the provision of midwifery services such as counseling to pregnant women the importance of delivery by health workers in health facilities.
\end{abstract}

Keywords: Causes, Stillbirth, Labor 


\section{PENDAHULUAN}

Kelahiran mati (stillbirth) adalah peristiwa atau kondisi yang terjadi sebelum ekspulsi lengkap atau ekstraksi yaitu bayi mengalami kematian, tanpa ada tanda kehidupan.Data dari World Health Organization (WHO) melaporkan bahwa setiap hari lebih dari 7.200 bayi lahir mati. Sebagian besar di antaranya $98 \%$ terjadi di negara-negara berpendapatan rendah hingga sedang. ${ }^{1}$

Angka Kematian Neonatal (AKN) di Indonesia menurut Kemenkes (2016) sebesar 19/1000 kelahiran. Kasus bayi lahir mati di Jawa Barat yang dilaporkan yaitu sebesar 3,097 kematian dari 935,003 kelahiran, namun angka lahir mati (dilaporkan) tersebut belum tentu menggambarkan angka lahir mati yang sebenarnya. $^{2}$

Banyak faktor yang berkontribusi terhadap tingginya angka kematian ibu dan angka kematian neonatus. Menurut Saifuddin (2010) penyebab kematian pada bayi baru lahir

diantaranya adalah faktor proses persalinan seperti partus lama, posisi janin, proses

persalinan, tempat persalinan dan penolong persalinan. $^{3}$ Menurut CEMACH 2007 Penyebab utama lahir mati umumnya dikelompokkan menjadi anomali kongenital berat atau letak (16\%), hemoragi antepartum

(8\%) dan penyebab intrapartum (7\%) serta lebih dari $50 \%$ kasus tidak jelas penyebabnya. ${ }^{4}$

Hasil penelitian yang dilakukan oleh Anwar (2005) yang berjudul Hubungan Kualitas Pemeriksaan Antenatal Dengan Kematian Perinatal di Kabupaten Banyumas didapatkan penyebab bayi lahir mati karena persalinan tidak normal sebanyak $20.5 \%$ dan ditolong oleh tenaga bukan kesehatan sebanyak $16.3 \% .{ }^{5}$ Selanjutnya penelitian yang dilakukan oleh Noorhalimah (2015) yang berjudul Faktor-Faktor yang Berhubungan dengan Kematian Neonatal di Kabupaten

Tapin menemukan bahwa terdapat hubungan yang bermakna antara kematian neonatal

dengan penolong persalinan dengan $\mathrm{p}$ value $0,000.6$

Penelitian lain yang dilakukan oleh Djaja (2009) yang berjudul Tren Lahir mati dan Kematian Neonatal di Indonesia hasil Survei
Kesehatan tahun 1995-2007 mendapatkan bahwa faktor ibu penyebab bayi lahir mati dan kematian neonatal dini diantaranya infeksi intrapartum (3.6\%), presentasi, posisi abnormal, disproporsi selama persalinan (3.6\%), persalinan letak bokong dan ekstraksi $(5.5 \%)$, proses kelahiran normal $(80.8 \%)$, vakum dan operasi SC (19.2\%), tempat persalinan di rumah $(54.4 \%)$, di fasilitas kesehatan $(43.3 \%)^{7}$

Berdasarkan penelusuran data di Kabupaten Tasikmalaya, angka kejadian bayi lahir mati pada tahun 2016 sebanyak 213 kasus $(0.68 \%)$ dari 31.199 kelahiran, sedangkan pada 2017 sebanyak 187 kasus (0.6\%) dari 30.940 kelahiran, melihat dari data tersebut kasus bayi lahir mati mengalami penurunan bila dibandingkan dengan tahun sebelumnya ${ }^{8}$

Meskipun mengalami penurunan tetapi kematian bayi lahir mati masih menjadi permasalahan yang perlu diketahui sebabnya sehingga dapat melakukan pencegahan dan penatalaksanaan terhadap faktor penyebab bayi lahir mati khususnya pada proses persalinan. Sehubungan hal tersebut maka saya melakukan penelitian ini, guna untuk mengetahui penyebab bayi lahir mati pada proses persalinan.

Penelitian ini bertujuan untuk mengetahui gambaran penyebab bayi lahir mati (stillbirth) pada proses persalinan di kabupaten Tasikmalaya tahun 2017.

\section{METODE PENELITIAN}

Jenis penelitian ini adalah kuantitatif dengan metode deskriptif, ${ }^{8}$ dengan menggunakan metode ini dapat mengetahui penyebab bayi lahir mati (stillbirth) pada proses persalinan di kabupaten Tasikmalaya tahun 2017.

Populasi dalam penelitian ini adalah ibu yang mengalami bayi lahir mati pada tahun 2017 dan teknik pengambilan sampel menggunakan total sampling yaitu seluruh populasi yang berjumlah 187 ibu yang mengalami stillbirth

Pengambilan data kasus stillbirth dalam penelitian ini dilakukan di satu tempat, dimana sebelumnya peneliti melakukan koordinasi dan kerja sama dengan pihak Dinas kesehatan 
untuk menginformasikan kepada semua bidan koordinator tiap Puskesmas untuk mengumpulkan partograf, buku KIA dan otopsi verbal kasus bayi lahir mati. Peneliti dengan pihak dinas kesehatan melakukan kontrak waktu dan tempat pengambilan data tersebut yakni di Hotel Horison Tasikmalaya pada tanggal 30 Mei 2018.

Instrumen yang digunakan dalam melakukan penelitian ini berupa format isian untuk merekap data-data yang sudah tersedia dalam Otopsi verbal dan Partograf yang ada di setiap puskesmas dan bidan desa terkait bayi lahir mati untuk mencari data tentang penolong persalinan, tempat persalinan dan penyulit persalinan. Kemudian data dianalisis secara univariat dan disajikan dalam bentuk distribusi frekuensi.

\section{HASIL DAN PEMBAHASAN}

\section{Karakteristik Responden}

Tabel 1 Distribusi Frekuensikarakteristik usia ibu yang melahirkan bayi dengan stillbirth

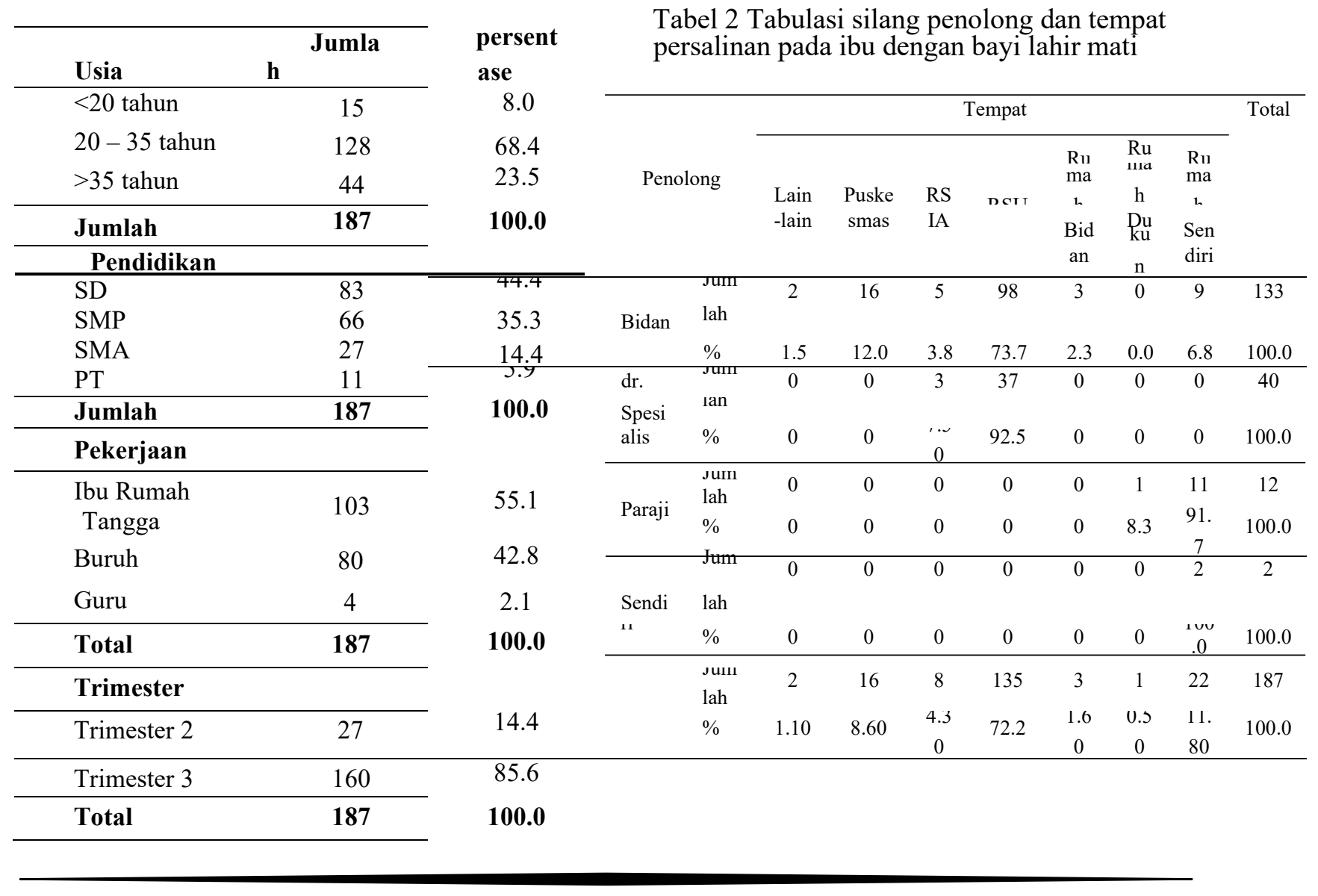


Penolong persalinan pada kasus stillbirth sebagian besar dilakukan oleh bidan sebanyak 133 orang $(71.1 \%)$, dokter spesialis sebanyak 40 orang $(21.4 \%)$, paraji sebanyak 12 orang (6.4\%) dan lain - lain (dilakukan sendiri) sebanyak 2 orang (1.1\%). Tempat persalinan kejadian stillbirth, sebagian besar terjadi pada rumah sakit umum (RSU) yaitu sebanyak 135 orang $(72.2 \%)$ dan paling sedikit terjadi di perjalanan saat merujuk ke rumah sakit yaitu 2 orang $(1.1 \%)$. Adapun tempat persalinan non fasilitas kesehatan pada kasus kejadian stillbirth paling banyak terjadi di rumah sendiri yaitu 22 orang $(11.8 \%)$ dan rumah dukun sebanyak 1 orang $(0.5 \%)$.

Berdasarkan hasil penelitian didapatkan bahwa menunjukkan bahwa penolong persalinan pada kasus stillbirth sebagian besar dilakukan oleh bidan Melihat dari data tersebut sebagian besar penolong persalinan pada kasus stillbirth adalah tenaga kesehatan yaitu bidan dan dokter spesialis kandungan. Hal ini sesuai dengan Depkes RI (2009) yang mengatakan bahwa Pertolongan persalinan oleh tenaga kesehatan adalah

pelayanan kesehatan yang diberikan oleh tenaga kesehatan seperti bidan, dokter dan tenaga medis lainnya. ${ }^{9}$

Banyaknya penolong persalinan pada kasus stillbirth tidak terlepas dari kasus rujukan. Dalam hal ini bidan yang melakukan pertolongan persalinan pertama kali melakukan diagnosa kebidanan, dari hasil diagnosa tersebut dapat diambil suatu keputusan sehingga harus dilakukan rujukan ke fasilitas kesehatan yang lebih tinggi.

Pada kasus stillbirth penolong terbanyak adalah bidan, dimana dalam hal ini bidan yang melakukan pertolongan adalah bidan yang bekerja di rumah sakit umum maupun rumah sakit ibu dan anak dengan pengawasan dokter spesialis dan alat penunjang yang lengkap dan kasus terbanyak yang dibantu oleh bidan adalah kasus IUFD dimana janin sudah dinyatakan meninggal didalam kandungan dan harus segera dikeluarkan.

$\begin{array}{llr}\quad \text { Pada prinsipnya, penolong } & \text { persalinan } \\ \text { hal-hal } & \text { memperhatikan } & \text { metode } \\ \text { sterilisasi/pencegahan infeksi, } & \text { standar } \\ \text { pertolongan persalinan yang sesuai } & \text { stand } \\ \text { pelayanan dan merujuk kasus yang } & \end{array}$

memerlukan tingkat pelayanan yang lebih tinggi

Lee, Anne C. et.all (2011) dalam penelitiannya menemukan bahwa di antara 24 531 kelahiran, angka kelahiran mati adalah 35,4 per 1.000 kelahiran (tingkat kelahiran bayi saat lahir 21,2 per 1000 kelahiran). Mayoritas (69\%) kematian maternal intrapartum menyebabkan bayi lahir mati dengan penolong persalinan, sebagian besar kelahiran terjadi di rumah tanpa petugas kelahiran yang terampil. ${ }^{10}$

Ibu yang memilih pertolongan persalinan oleh paraji. artinya paraji masih berperan dalam pertolongan persalinan. Hal tersebut mengindikasikan bahwa masih adanya masyarakat yang percaya kepada dukun paraji sebagai orang yang terdekat secara psikologis, selain itu banyak faktor yang menyebabkan persalinan oleh dukun paraji. Beberapa hal yang menjadi alasan dalam pemilihan penolong persalinan oleh paraji seperti pendapatan keluarga, jarak tempat tinggal dengan fasilitas kesehatan dan adat istiadat terhadap persalinan dengan paraji.

Berdasarkan hasil penelitian didapatkan bahwa tempat persalinan kejadian stillbirth, sebagian besar terjadi pada rumah sakit umum (RSU). Melihat dari data tersebut mengindikasikan sebagian besar kasus stillbirth terjadi di fasilitas kesehatan. Hal ini dapat diasumsikan dengan komplikasikomplikasi yang terjadi pada janin.

Rumah sakit umum menjadikan tempat kasus stillbirth terbanyak dibandingkan dengan fasilitas lain. Hal ini disebabkan karena RSU memiliki sarana dan prasarana yang lebih lengkap, sehingga penanganan pada kasus

komplikasi dapat optimal dan dapat dengan cepat cepat ditangani dan tidak perlu merujuk/membawa ke rumah sakit lain. Penolong persalinan bisa bidan ataupun dokter. Hasil penelitian ini didapatkan tempat persalinan pada kasus stillbirth di RSIA yaitu sebanyak 4.3\%. Secara umum RSIA sama dengan di rumah sakit bersalin, namun lebih lengkap karena memiliki fasilitas untuk perawatan bayi/anak jika memerlukan perawatan lebih lanjut, jika terjadi gangguan setelah proses persalinan. Disebut rumah sakit ibu dan anak karena bukan hanya untuk ibu 
hamil dan melahirkan, tetapi juga wanita yang memerlukan pengobatan untuk penyakit kandungan.

Berdasarkan hasil penelitian ini didapatkan proses persalinan terbanyak yaitu persalinan secara normal (spontan) karena berdasarkan data kasus terbanyak yaitu IUFD tetapi ada juga beberapa kasus dengan persalinan buatan dan persalinan anjuran karena harus segera diterminasi sehingga dilakukan seksio caesaria, vakum ekstraksi dan di induksi.

Begitupun terkait dengan masalah pekerjaan dimana sebagian besar responden tidak bekerja atau sebagai IRT yaitu 103 orang $(55.1 \%)$. Hal ini tentu saja terjadi kontradiksi, dimana ibu memiliki waktu luang untuk melakukan pemeriksaan kehamilan sehingga ibu memiliki pengetahuan yang lebih terhadap kehamilannya sampai pada proses persalinannya, namun kesempatan tersebut tidak dimanfaatkannya.

Kulmala (2000) dalam penelitiannya menemukan bahwa 75\% dari subjek memiliki setidaknya satu karakteristik risiko yang umum diterima. hanya $30 \%$ dari responden yang memiliki karakteristik risiko dan melahirkan bukan di fasilitas kesehatan modern. 4 wanita meninggal, 127 mengalami komplikasi persalinan dan ada 52 kematian perinatal. Dari

ibu hamil beresiko dapat diprediksi sebagian

besar mengalami komplikasi persalinan atau

kematian perinatal. Nilai prediktif positif adalah serendah $20 \%$ untuk komplikasi persalinan dan $7 \%$ untuk kematian perinatal. ${ }^{11}$

Masalah lain adalah terdapat ibu yang memilih tempat persalinan di rumah sendiri atau rumah dukun dengan penolong persalinan

oleh non nakes. Memasuki usia kehamilan

trimester III, ibu serta suami atau keluarga pada umumnya sudah mempersiapkan tempat persalinan. Pemilihan tempat persalinan dapat didasarkan pada masalah jarak, ekonomi dan biaya serta kedekatan secara psikologis.

Dilihat dari segi regulasi pemerintah terkait dengan kesehatan reproduksi, maka menjadi keputusan dalam peraturan pemerintah melalui Making pregnancy Safer bahwa semua ibu hamil memerlukan perhatian serius dan mendekatkan pelayanan yang bermutu, berkesinambungan serta setiap persalinan wajib dilakukan di fasilitas kesehatan dengan penolong tenaga kesehatan yang profesional.

Namun pada kenyataannya, keputusan untuk memilih tempat persalinan didasarkan atas kemudahan dalam menjangkau tempat pelayanan tersebut, baik keterjangkauan dalam segi geografis maupun dalam hal ekonomi. Menurut Azwar (2011) syarat pokok pelayanan kesehatan yang baik adalah yang mudah dicapai oleh masyarakat. Pengertian ketercapaian yang di maksud di sini terutama dari sudut lokasi. Demikian untuk dapat mewujudkan pelayanan kesehatan yang baik, maka pengaturan distribusi sarana kesehatan menjadi sangat penting. Pelayanan kesehatan yang terkonsentrasi di daerah perkotaan saja dan sementara itu tidak di temukan di daerah pedesaan, bukanlah pelayanan kesehatan yang baik. $^{5}$

\section{Penyulit proses persalinan pada ibu dengan bayi lahir mati}

Tabel 3 Penyulit proses persalinan pada ibu dengan bayi lahir mati

\begin{tabular}{|c|c|c|c|}
\hline \multicolumn{2}{|c|}{ No. Penyulit Persalinan } & Jumlah & Persen \\
\hline \multicolumn{4}{|c|}{ 1. $\mathrm{Ya}$} \\
\hline \multicolumn{4}{|c|}{ a. Tidak Ada } \\
\hline & Kemajuan & \multirow[t]{2}{*}{9} & \multirow[t]{2}{*}{4.8} \\
\hline & $\begin{array}{l}\text { Dalam } \\
\text { Persalinan }\end{array}$ & & \\
\hline \multicolumn{2}{|r|}{ b. Letak Bokong } & 20 & 10.7 \\
\hline & $\begin{array}{l}\text { Malpresentasi, } \\
\text { Malposisi dan } \\
\text { Disproporsi }\end{array}$ & 8 & 4.3 \\
\hline & d. Distosia Bahu & 9 & 4.8 \\
\hline & e. Fetal Distress & 10 & 5.3 \\
\hline & f. Gemelli & 6 & 3.2 \\
\hline & g. Serotinus & 3 & 1.6 \\
\hline \multirow[t]{2}{*}{2.} & Tidak ada penyulit & 122 & 65.2 \\
\hline & Total & 187 & 100.0 \\
\hline
\end{tabular}

Ibu dengan bayi lahir mati yang tidak mengalami kemajuan persalinan sebanyak 9 orang $(4.8 \%)$, persalinan letak bokong sebanyak 20 orang $(10.7 \%)$, Malpresentasi, malposisi dan disproporsi sebanyak 8 orang 
(4.3\%), mengalami penyulit distosia bahu sebanyak 9 orang $(4.8 \%)$, fetal distress sebanyak 10 orang (5.3\%), gemelli sebanyak 5 orang (3.2\%), Serotinus sebanyak 3 orang $(1.6 \%)$. sedangkan yang tidak mengalami penyulit (IUFD) sebanyak 122 orang (65.2\%).

a. Tidak ada kemajuan persalinan Berdasarkan hasil penelitian

menunjukkan bahwa ibu dengan bayi lahir mati yang tidak mengalami kemajuan persalinan. Setiap jam seharusnya serviks membuka minimal selebar $1 \mathrm{~cm}$ dan kepala janin seharusnya turun ke dalam rongga panggul minimal sebanyak $1 \mathrm{~cm}$. Jika hal tersebut tidak terjadi, mungkin janin terlalu besar untuk melewati jalan lahir dan perlu dilakukan persalinan dengan bantuan forceps atau operasi sesar.Jika jalan lahir cukup lebar tetapi persalinan tidak maju, maka diberikan oksitosin melalui infus untuk merangsang kontraksi rahim yang lebih kuat. ${ }^{12}$

Berdasarkan hasil pengkajian terhadap lembar partograf ditemukan beberapa data yang terkait dengan penyulit kehamilan. dari hasil penelusuran beberapa data ditemukan di dalam partograf kolom DJJ sudah tidak ditemukan. Jika kondisi demikian, artinya janin sudah dinyatakan mati dalam kandungan, hal ini disebabkan oleh gawat janin. Berdasarkan data lain ditemukan bahwa bayi meninggal pada saat dilakukan seksio caesaria karena dalam hal ini bidan telat merujuk ibu ke rumah sakit.

b. Persalinan dengan letak bokong

Hasil penelitian didapatkan ibu dengan bayi lahir mati yang mengalami persalinan letak bokong.Persalinan letak bokong adalah persalinan untuk melahirkan janin yang membujur dalam uterus dengan bokong atau kaki pada bagian bawah dimana bokong atau kaki akan dilahirkan terlebih dahulu daripada anggota badan lainnya. Kehamilan pada bayi dengan presentasi bokong dimana bayi letaknya sesuai dengan sumbu badan ibu, kepala berada pada fundus uteri, sedangkan bokong merupakan bagian terbawah di daerah pintu atas panggul atau simfisis.$^{11}$ c. Malpresentasi, malposisi, disproporsi Berdasarkan data penelitian didapatkan ibu dengan bayi lahir mati yang mengalami malpresentasi, malposisi dan disproporsi. Melihat dari data tersebut mengindikasikan sebagian kecil posisi janin dalam kandungan posisi janin tidak berada dalam posisi atau letak yang normal. Komplikasi dari malpresentasi diantaranya kematian perinatal yang diakibatkan oleh prolaps tali pusat, trauma pada janin, asfiksia karena prolaps tali pusat, kompresi tali pusat, pelepasan plasenta dan kepala macet. Smith, Gordon C S and Fretts, Ruth C menyebutkan bahwa kebanyakan bayi lahir mati berhubungan dengan disfungsi plasenta, yang pada banyak wanita terbukti dari paruh pertama kehamilan dan dikaitkan dengan hambatan pertumbuhan janin. ${ }^{13}$ Kelahiran mati juga dikaitkan dengan proses persalinan karena kelainan passanger seperti posisi fetal. Posisi fetus yang abnormal menyulitkan cara dan proses persalinan. Pada tahap pengeluaran, fetal kesulitan mendapat oksigen, sulit dilakukan ada tes skrining yang efektif yang secara jelas untuk mencegah kematian saat intrapartum

d. Distosia bahu

Berdasarkan data hasil penelitian didapatkan ibu dengan bayi lahir mati yang mengalami penyulit distosia. Distosia bahu merupakan salah satu kasus kegawatdaruratan paling serius pada proses kelahiran. Kondisi ini disebabkan oleh impaksi bahu anterior janin pada simfisis pubis ibu atau yang jarang dijumpai, sisi posterior janin pada promontory sacrum setelah kepala bayi lahir sehingga perlu dilakukan perasat obstetri tambahan untuk melepaskan bahu, jika bayi tidak lahir dalam beberapa menit setelah munculnya kepala kemungkinan bayi akan meninggal. ${ }^{14}$

e. Fetal Distress

Hasil penelitian didapatkan ibu dengan bayi lahir mati yang mengalami penyulit berupa fetal distress. Kondisi tersebut mengindikasikan sebagian kecil denyut jantung janin tidak normal atau $<120$ atau 
$>160 \mathrm{x} /$ menit Selama persalinan, denyut jantung janin dimonitor setiap 30 menit dengan stetoskop janin (fetoskop) atau dimonitor terus dengan pemantau denyut jantung elektronik. Pemantauan denyut jantung janin merupakan cara yang paling mudah untuk mengetahui adanya gawat janin. Jika terdengar denyut jantung yang abnormal, dilakukan tindakan korektif, seperti memberikan oksigen kepada ibu, menambah jumlah cairan infus dan meminta ibu untuk berbaring miring ke kiri. Jika tindakan tersebut tidak berhasil memperbaiki denyut jantung yang abnormal, maka dilakukan persalinan forsep atau operasi sesar. ${ }^{15}$

Gardosi, Jason et all menemukan dalam penelitiannya yaitu analisis multivariabel untuk mengidentifikasi risiko penyebab dari lahir mati yaitu pembatasan pertumbuhan dan gawat janin. Sebagai faktor risiko yang berpotensi dimodifikasi, obesitas, merokok pada kehamilan dan hambatan gawat janin bersama-sama menyumbang $56,1 \%$ dari bayi lahir mati. Kehadiran variabel gawat janin merupakan risiko tertinggi, dan ini dialami pada kehamilan di mana ibu tidak merokok. Restriksi gawat janin juga memiliki risiko populasi terbesar untuk lahir mati dan lima kali lipat lebih besar jika tidak terdeteksi dalam antenatal. ${ }^{16}$

f. Gemelli (kehamilan ganda)

Berdasarkan data hasil penelitian didapatkan bahwa ibu dengan bayi lahir mati yang mengalami penyulit persalinan berupa gemelli. Kehamilan ganda ialah satu kehamilan dengan dua janin atau lebih. ${ }^{17}$ Kehamilan kembar dikatakan memiliki risiko yang lebih tinggi karena dalam kehamilan sering terjadi beragam komplikasi yang cukup berbahaya. Komplikasi yang terjadi pada ibu hamil kembar antara lain kemungkinan bayi lahir dalam kondisi meninggal (stillbirth), single or multiple fetal demise (satu atau kedua bayi menderita penyakit berbahaya yang mematikan), single fetal demise and co-twin morbidity (satu bayi meninggal dan kembarannya mengalami sakit), single fetal demise and maternal morbidity (kematian salah satu bayi dan komplikasi kesehatan pada ibu). ${ }^{15}$

\section{g. Serotinus}

Berdasarkan data hasil penelitian didapatkan bahwa ibu yang mengalami stillbirth karena serotinus. Pada kasus ibu yang mengalami serotinus yaitu mulai merasakan gerakan janin berkurang dan sama sekali tidak ada gerakan janin, lalu ibu memeriksakan kandungannya dan didapatkan bahwa janin ibu telah mengalami kematian didalam rahim ibu (IUFD). Keadaan klinis pada kehamilan serotinus adalah gerakan janin berkurang dan kulit bayi ditemukan maserasi, mekonium berwarna hijau dan akan timbul warna kekuningan pada kuku, kulit dan tali pusat.$^{14}$

Berdasarkan hasil penelitian ini didapatkan bahwa pada sebagian besar responden tidak mengalami penyulit persalinan, namun adanya kasus stillbirth pada penelitian ini dapat disebabkan oleh faktor lain seperti IUFD. Hal ini didasarkan pada data dari otopsi verbal didapatkan IUFD mencapai 122 kasus.

IUFD adalah keadaan tidak adanya tanda tanda kehidupan janin dalam kandungan ibu pada usia kehamilan lebih dari 20 minggu. Hal ini mengindikasikan bahwa kasus stillbirth sebagian besar disebabkan karena memang janin sudah mati di dalam kandungan. Kasus IUFD merupakan kasus terbanyak terjadinya stillbirth di Kabupaten Tasikmalaya tahun 2017. Faktor penyebab terjadi IUFD pada ibu hamil di Kabupaten Tasikmalaya tahun 2017 yaitu perdarahan, anemia, preeklamsia, KPD dan serotinus.

\section{KESIMPULAN}

1. Penolong persalinan pada ibu dengan bayi lahir mati di Kabupaten Tasikmalaya sebagian besar adalah bidan (71.1\%)

2. Tempat persalinan pada ibu dengan bayi lahir mati di Kabupaten Tasikmalaya sebagian besar di RSU (72.2\%).

3. Penyulit proses persalinan pada ibu dengan bayi lahir mati di Kabupaten Tasikmalaya sebagian besar adalah letak bokong $(10.7 \%)$. 


\section{SARAN}

1. Bagi Bidan

Sebaiknya bidan sebagai penolong persalinan dapat melakukan upaya sedini mungkin untuk pencegahan komplikasi pada ibu selama kehamilan, persalinan dan pada bayi. Bidan disarankan dapat memberikan pelayanan sesuai standar pelayanan kebidan dan mengoptimalkan pemberian pelayanan kebidanan seperti konseling dan penyuluhan kepada ibu hamil pentingnya persalinan oleh nakes di fasilitas kesehatan. ${ }^{14}$

2. Ibu bersalin

Disarankan ibu beserta keluarga dapat memilih tempat dan penolong persalinan secara matang yaitu bersalin di fasilitas kesehatan seperti bidan, RSU dan RSIA dengan penolong persalinan oleh tenaga kesehatan yang profesional

3. Bagi Dinas Kesehatan Kabupaten Tasikmalaya

Sebaiknya pihak Dinas Kesehatan Kabupaten Tasikmalaya dapat membuat rujukan untuk meningkatkan sumber daya manusia dan sumber daya kesehatan untuk menurunkan angka kejadian lahir mati di Kabupaten Tasikmalaya.

4. Bagi Peneliti

Perlu dilakukan penelitian lebih lanjut mengenai hal serupa dengan metode kualitatif terhadap kasus stillbirth dengan terfokuskan pada riwayat kehamilan ibu dan proses persalinan ibu dengan stillbirth. Diharapkan peneliti lain dapat melakukan upaya untuk mencegah terjadinya IUFD pada ibu hamil.

\section{DAFTAR PUSTAKA}

1. VOA Indonesia,. Sebagian Besar Kematian Bayi yang Baru Lahir Terjadi di Negara Berkembang. 2011 Tersedia dari https://www.voaindonesia.com/diakses tanggal 20 Februari 2018

2. Dinas Kesehatan Provinsi Jawa Barat, Profil kesehatan provinsi Jawa Barat tahun 2012, Bandung.Dinas Kesehatan Provinsi Jawa Barat.
3. Saiffudin, Buku Acuan Nasional Pelayanan Kesehatan Maternal dan Neonatal. Jakarta. Yayasan Bina Pustaka Sarwono Prawirohardjo,2010.

4. Chapman Vicky, Persalinan Dan Kelahiran Asuhan Kebidanan. Jakarta : EGC, 2013.

5. Anwar,Hubungan Kualitas Pemeriksaan Antenatal Dengan Kematian Perinatal di Kabupaten Banyumas, 2005.

6. Noorhalimah, Faktor-Faktor yang Berhubungan dengan Kematian Neonatal di Kabupaten Tapin, 2015

7. Djaja.dkk, Tren Lahir mati dan Kematian Neonatal di Indonesia hasil Survei Kesehatan tahun 1995-2007, 2009

8. Dinas Kesehatan Kabupaten Tasikmalaya, Profil kesehatan Kabupaten Tasikmalaya, Tasikmalaya.Dinas Kesehatan Kabupaten Tasikmalaya, 2017

9. Depkes, Keputusan Menteri Kesehatan tentang registrasi dan praktik bidan. 2009 http://www.depkes.go.id

10.Lee, Anne C. et.all ,Community-based stillbirth rates and risk factors in rural Sarlahi, Nepal. International Journal of Gynecology and Obstetrics. International Journal of Gynecology and Obstetrics, 113(3), 199-204, 2011

11.Kulmala, The relationship between antenatal risk characteristics, place of delivery and adverse delivery outcome in rural Malawi. Acta Obstetricia et Gynecologica Scandinavica, 2000

12. Manuaba, Ilmu Kebidanan, Penyakit Kandungan dan KB. EGC. Jakarta 2010

13. Fretts, et, all, Stillbirth :Common Causes and Prevention, 2007

14. Nugroho, Patologi Kebidanan. Nuha Medika. Yogyakarta, 2012

15. Benson, Ralph, Buku Saku Obstetri dan Ginekologi. EGC. Jakarta, 2009

16. Gardosi, Jason, et. All, Maternal and fetal risk factors for stillbirth: population based study. BMJ (Clinical research ed.) 2013

17. Saifuddin, Pelayanan Kesehatan Maternal dan Neonatal. Jakarta. Yayasan Bina Pustaka Sarwono Prawirohardjo. 2009

18. Notoatmodjo, Metodologi penelitian kesehatan. PT Rineka Cipta. Jakarta.2001 